\title{
EXCHANGE RATE PASS-THROUGH UNDER THE EFFECT OF BREXIT: AN EMPIRICAL ANALYSIS ON THE UNITED KINGDOM
}

\author{
DOI: 10.17261/Pressacademia.2021.1404 \\ JBEF- V.10-ISS.2-2021(1)-p.47-57
}

\section{Onur Seker}

Beykent University, Graduate School, Department of Economics, Istanbul, Turkey. seker.s.onur@gmail.com, ORCID : 0000-0003-1940-7452

To cite this document

Seker, O.,(2021). Exchange rate pass-through under the effect of Brexit: an empirical analysis on the United Kingdom. Journal of Business, Economics and Finance (JBEF), 10(2), 47-57.

Permanent link to this document: http://doi.org/10.17261/Pressacademia.2021.1404

Copyright: Published by PressAcademia and limited licensed re-use rights only.

\section{ABSTRACT}

Purpose - This study aimed to examine the effects of the environment of uncertainty caused by the United Kingdom (UK) people's decision to leave the European Union (EU) as a result of the referendum held on June 23, 2016, on the UK's economy. In this context, the effects of fluctuations in exchange rates on prices (consumer and producers) and profitability rates were analyzed.

Methodology - The data set was divided into the Brexit period (2016:06 - 2020:02) and the pre-Brexit period (2010:01 - 2016:05) for a comparative analysis of the effect of Brexit on ERPT. Structural Vector Autoregressions (SVAR) models were used to get rid of the non-theoretical structure of standard VAR models, and the McCarthy (1999) model was taken as the reference for the theoretical framework of the model. The analysis of variance decomposition was performed to examine the relationship between the variables using the dynamic structure of VAR models.

Findings- The unexpected result of the referendum and the environment of uncertainty caused by this result in the UK's economy had negative effects, especially on producer prices. It was observed that the increase in costs, which was due to fluctuations in the exchange rate caused by the environment of uncertainty after the referendum, could not be fully reflected on consumer prices by firms. According to the results of the analysis of variance decomposition, while 5.55 percent of changes in producer prices and 4.44 percent of changes in consumer prices in the Pre-Brexit period were explained by changes in the exchange rate, these rates were found to be 16.45 percent and 6.41 percent, respectively, during the Brexit period.

Conclusion- During the Brexit period, it was observed that firms could not reflect the increases in costs to prices and this situation caused a decrease in the profitability rates of the firms. Some of these decreases in the profitability ratios of firms are expected to be permanent. However, it will be possible to make a distinction between structural effects and periodic effects after the terms of the agreement are determined. Considering the overlap of two important global events, such as the COVID-19 pandemic and the Brexit process, it is observed that the UK's economy is going through an extremely sensitive period. Accordingly, the monetary authorities in the UK should take into account many more variables while taking decisions during this period, unlike previous periods.

Keywords: Exchange rate pass-through, inflation, Brexit, variance decomposition, SVAR analysis. JEL Codes: C32, E31, F31

\section{INTRODUCTION}

The Brexit referendum, in which the UK people decided to leave the EU, was the beginning of a new period both politically and economically for both sides. Although Brexit had political consequences such as the resignation of the Prime Minister David Cameron and the internal disputes within the main opposition Labor Party, its economic effects were among the most important issues on the UK's agenda.

Although it was observed that the two options were close to each other in the surveys conducted before the referendum, betting markets considered that undecided voters were likely to choose to remain in the EU by 85 percent. The effect of the unexpected result of the referendum on the financial markets was instantaneous, and on June 24, 2016, the FTSE 100 stock market index fell by 8.1 percent against the USD and 5.8 percent against the Euro (Breinlich, Leromain, Novy and Sampson, 2019). After the 
referendum, many economists discussed Brexit from many different aspects such as its effects on the financial markets (Schiereck, Kiesel and Kolaric 2016; Belke, Dubova and Osowoski 2016; Hohlmeier and Fahrholz 2018), regional effects (Dhingra, Machin and Overman 2017) and the investments (Dhingra, Ottaviano, Sampson and Van Reenen 2016a; Welfens and Baier 2018).

In this study, the environment of uncertainty caused by the process of the UK's withdrawal from the EU and accordingly the effect of the fluctuations in the value of the British Pound (GBP) on producer and consumer prices were analyzed. The data set was divided into two different parts as the pre-Brexit period and the Brexit period for a comparative analysis of this effect, and the McCarthy (1999) model was taken as a reference for the methodological framework of the study. The interaction between the variables was calculated by the analysis of variance decomposition using the dynamic structure of VAR models. The results are like other studies in the literature with regard to the pass-through calculated for the pre-Brexit period and the decreasing profitability ratios of companies (Jimenez-Rodriguez and Morales-Zumaquero 2016; Winters and Fernandes 2018). However, unlike other studies, the analysis of both periods using the same econometric methods and the comparison of the results made a significant contribution to the literature.

\section{LITERATURE REVIEW AND TAYLOR'S HYPOTHESIS}

In this section, the literature on ERPT will be examined in three different sections. While the definitions of ERPT will be included in the first section, the theoretical framework of Taylor's hypothesis and studies based on this hypothesis will be included in the second section, and the methods used in the calculation of ERPT will be included in the third section.

Although ERPT is basically defined as the reflection of changes in exchange rates on prices, there are also different definitions in the economic literature. Goldberg and Knetter (1997) defined ERPT as the percentage change in local currency import prices resulting from a one percent change in the exchange rate between the exporting and importing countries. Hooper and Mann (1989) discussed it within a narrower context by focusing on the variables used in the study, and they defined it as the change in import prices caused by changes in the nominal exchange rate. Menon (1996) defined it as the extent to which changes in the exchange rate are reflected in the target currency prices of the traded goods.

Although the inclusion of ERPT in the economic literature goes back to earlier dates, Taylor (2000) has been an important reference point in studies on ERPT by arguing that there is a relationship between ERPT and inflation rates. According to Taylor, firms have a certain power in determining the price of the product they will put on the market. Increases in costs and changes in the prices of firms with which they compete are the main variables that affect the pricing power of firms. In an environment where price stability is provided, the pricing power of firms is lower compared to periods of high inflation without price stability. Taylor's hypothesis is based on the differential pricing model. The linear demand equation for the goods of a firm is presented in equation 1 (Otani, Shiratsuka and Shirota 2003);

$\theta_{t}=\varepsilon_{t}-\pi\left(\beta_{t}-P_{t}\right)$

$\theta \mathrm{t}$ represents the production of the firm's goods, Pt represents the average price of the goods produced by competing firms, $\varepsilon \mathrm{t}$ represents the random shift by demand, $\pi$ represents the opposite of the firm's power. $\pi$ being equal to infinity represents perfect competition. Let us assume that the firm has predetermined the price for the next four periods and reviewed the determined price for every four periods. Furthermore, if it is assumed that $\mathrm{Ct}$ represents the marginal cost and $\beta \mathrm{t}$ represents the price determined by the firm, the firm's expected profit for four periods can be expressed as follows:

$\sum_{i=0}^{3} E_{t}\left(\beta_{t} \theta_{t+i}-C_{t+i} \theta_{t+i}\right)$

$\theta$ t represents the production of the firm's goods, Pt represents the average price of the goods produced by competing firms, $\varepsilon$ t represents the random shift by demand, $\pi$ represents the opposite of the firm's power. $\pi$ being equal to infinity represents perfect competition. Let us assume that the firm has predetermined the price for the next four periods and reviewed the determined price for every four periods. Furthermore, if it is assumed that Ct represents the marginal cost and $\beta \mathrm{t}$ represents the price determined by the firm, the firm's expected profit for four periods can be expressed as follows:

$\beta_{t}=0.125 \sum_{i=0}^{3}\left(E_{t} C_{t+i}+E_{t} P_{t+i}+E_{t} \varepsilon_{t+i} / \beta\right)$

When the optimal price equation number 3 is applied to a firm that imports products from foreign countries and sells them in its domestic market, three different results will be obtained as follows;

- Changes in the exchange rate affect the marginal cost, and accordingly, the firm's selling prices change, 
- Even though the import cost increases as a result of changes in the exchange rate, the firm attempts to avoid price increases as much as possible,

- Weak market power decreases the firm's pricing power in response to demand shocks. Accordingly, the possibility of the firm to reflect the increases in cost to the product price decreases.

In his study, which was another one of the turning points of the studies on ERPT, Taylor (2000) found that high inflation periods increased the ability of firms to reflect their costs on prices and that this situation reversed in the low inflation period. After Taylor (2000), a significant part of the studies on pass-through was based on the testing of this hypothesis. When studies in the literature are reviewed, it is observed that Taylor's hypothesis has been examined in many different countries with different data sets and different methods. Although most of the results obtained in these studies support Taylor's hypothesis, there are also studies in which the hypothesis could not be confirmed. Ca 'Zorzi, Hahn, and Sanchez (2007) concluded that there was a positive correlation between inflation rates and pass-through in 10 of the 12 selected developing countries (excluding Argentina and Turkey). In parallel with this result, while Choudhri and Hakura (2006) confirmed the validity of Taylor's hypothesis in 71 countries including both developing and industrialized countries between 1979-2000, Baqueiro, Díaz de Leon, and Torres (2003) confirmed it in 16 countries with a flexible exchange rate regime, and Loloh (2014) confirmed it in Ghana between 1994-2012.

Studies in the literature generally usually the high inflation periods experienced in the 1990s. During this period, many countries adopted the inflation targeting regime and provided price stability. Bouakez and Rebei (2005) in Canada, Baharumshah, Sirag and Soon (2017) in Mexico, and Taguchi and Bolortuya (2019) in Mongolia observed that the decreasing inflation rates in the period after the inflation targeting regime was implemented also reduced the pass-through.

Contrary to Taylor's hypothesis, Parsons and Kiyotaka (2008) concluded that transitivity did not change over time in Japan. Campa and Goldberg (2002) concluded that there was a weak correlation between high inflation and exchange rate pass-through to import prices.

Many different methods were used for the calculation of ERPT in the literature. The SVAR model used by McCarthy (1999) while calculating ERPT in 9 different developed countries and its constraints have been among the most referenced methods in this field. In other studies, in which the same method was used, while Gueorguiev (2003) and Ocran (2010) concluded that exchange rate pass-through to producer prices was higher compared to its pass-through to consumer prices, Stulz (2007) concluded that changes in the exchange rate in Switzerland rapidly passed to import prices. However, this passing was incomplete in the long term. Ito and Sato (2006) concluded that the pass-through effect of the exchange rate on import prices was high in the East Asian economies that were affected by the crisis. However, the pass-through effect on consumer prices was low in countries other than Indonesia, and Leigh and Rossi (2002) concluded that the exchange rate pass-through to wholesale prices was higher compared to pass-through to consumer prices in Turkey.

Another one of the most used methods in calculating the pass-through in recent years has been the nonlinear time series. In their study on the USA conducted using the STAR method, Shintani, Terada-Hagiwara, and Yabu (2013) concluded that the decrease in pass-through in the 1980s and 1990s was associated with inflation rates. In his study on Tunisia between 2011 Q4 - 2019Q4, Wissem (2020) used the LSTAR method and concluded that there was a high exchange rate pass-through to inflation through external debt in both regimes. In addition to the regime change models used in previous studies, the NARDL method is also highly preferred in this field. In their study on the Czech Republic between 1999M05 - 2018M12, Nasir, Huynh, and Vo (2020) determined that ERPT had significant effects on inflation expectations. In their study conducted on Sudan between 1992Q1-2015Q2, Baharumshah, Sirag, and Nor (2017) concluded that inflation was largely due to sharp fluctuations in the exchange rate and that the effect of oil prices on prices was insignificant.

\section{ECONOMIC EFFECT OF BREXIT}

It is necessary to analyze the dynamics of the UK economy to observe the effect that Brexit can have on the UK. Before joining the European Economic Community (EEC) in 1973, approximately a third of the UK's trade was with the EEC. However, in 2014, the other $27 \mathrm{EU}$ members accounted for 45 percent of the UK's exports and 53 percent of its imports. The UK's exports to the EU constituted 13 percent of the UK's national income. This high volume of trade between the two sides also provided lower prices and household's access to higher quality goods and services (Dhingra, Ottaviano, Sampson and Van Reenen 2016b).

International organizations and investors predict that commercial relations that are damaged will cause a long-term slowdown in the growth rates of the UK economy. On the other hand, it is expected that Brexit will also affect not only the UK and the EU, but also the world economies. In particular, the commercial position to be taken by the countries that are not members of the EU but 
have trade agreements after Brexit will significantly affect the UK's economy. The expected effects of Brexit in the short, medium and long term can be summarized as shown in (figure no 1 ).

Figure 1: Short, Medium, and Long-Term Effects of Brexit

\begin{tabular}{|c|c|c|}
\hline United Kingdom & European Union (27) & World Economics \\
\hline 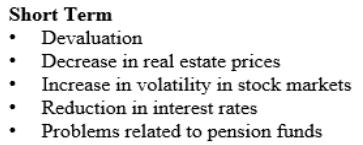 & $\begin{array}{l}\text { Short Term } \\
\text { - Value increase in national currency } \\
\text { - Depreciation in stocks } \\
\text { such as in interest rates in countries } \\
\text { France }\end{array}$ & $\begin{array}{l}\text { Short Term } \\
\text { - Capital inflows to emerging markets } \\
\text { Value increase in currencies }\end{array}$ \\
\hline 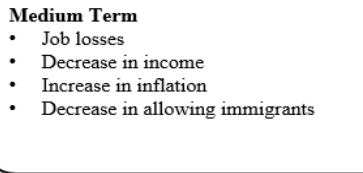 & $\begin{array}{l}\text { Medium Term } \\
\text {. Job losses } \\
\text { - Decrease in income } \\
\text { - } \text { Increase in inflation } \\
\text { countries } \\
\text { - } \text { Disputes over the EU budget }\end{array}$ & $\begin{array}{l}\text { Medium Term } \\
: \text { Increase in income } \\
\text { - Risk of a new Asian crisis } \\
\text { Increased effectiveness of G20 and } \\
\text { OECD }\end{array}$ \\
\hline 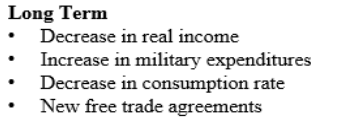 & $\begin{array}{l}\text { Long Term } \\
\text { Decrease in real income } \\
\text { - Increase in military expenditures } \\
\text { - Great EU and euro area reform }\end{array}$ & $\begin{array}{l}\text { Long Term } \\
\text { - More free trade agreements between the } \\
\text { UK and the EU } \\
\text { - Increase in real income } \\
\text { - Increased volatility in financial markets }\end{array}$ \\
\hline
\end{tabular}

Source: Welfens, 2018, p. 113.

The decision to leave the EU led to a high increase in uncertainty in the UK's economy. In the Brexit uncertainty index (BUI) prepared by the Bank of England, a significant increase was observed towards the end of 2018 due to the fact that the terms of the agreement could not be determined exactly. This uncertainty has adverse effects, especially on the value of the national currency. The long-term fate of the GBP depends on the terms of the EU-UK separation. The stricter the terms of the agreement are, the greater the adverse effects on the UK economy will be. It is expected that the GBP will be priced between 1.40 USD - 1.45 USD after a relatively soft Brexit and around 1 USD after a harsher Brexit. In addition to this situation, this uncertainty also has effects on firms. It is estimated that the level of productivity has decreased between 2 percent and 5 percent during the period since the referendum. A large part of this decrease is due to the time that senior managers in firms spend on Brexit planning (Pilbeam 2019). Apart from all these adverse effects, the new commercial partnerships to be established by the UK after Brexit will be the beginning of a new commercial period both in the UK and in different parts of the world.

When the position of the UK within the EU is considered, it is inevitable that Brexit will also have extremely important effects on the EU. In particular, the withdrawal of the UK, one of the most important financing resources within the union, is expected to cause worldwide economic insecurity against the union. Moreover, along with the conclusion of Brexit, a deficit of 13-15 billion Euros is expected to occur in the EU budget. Other member states will have to close this deficit. Apart from economic effects, Brexit will be a significant loss of power and prestige for the union since the UK is one of the most important military powers in the EU in many aspects.

When the terms of the agreement are finalized in the following periods, the environment of uncertainty in the UK economy is expected to improve. However, considering the customs controls, additional costs, and bureaucratic procedures, it will not come as a surprise for both parties of the agreement that some of the damage that occurred during the period of uncertainty will be permanent. Accordingly, it will take a long time to decompose the structural and periodic effects of Brexit on the UK economy.

\section{DATA AND METHODOLOGY}

In the analysis performed to examine the effect of Brexit on the exchange rate pass-through in the UK, the data set was divided into two periods as the Brexit period (2016:06-2020:02) and the pre-Brexit (2010:01-2016:05) period. The constraints of the SVAR model used in the study of McCarthy (1999) were referenced to calculate ERPT. The variables used in the analysis and the sources of the variables are presented in Table 1. 
Table 1: Variables and Sources

\begin{tabular}{lll}
\hline Designation of İndicator & Description & Source \\
\hline OIL & Brent Oil & St. Louis FED \\
IPI & Industrial Production İndex & OECD \\
OG & Output Gap & Obtained using the IPI variable \\
ER & Exchange rate (GBP/USD) & St. Louis FED \\
IMP & Import Prices & OECD \\
PPI & Producer Price Index & OECD \\
CPI & Consumer Price İndex & OECD \\
\hline
\end{tabular}

The Hodrick-Prescott filtering method was used to calculate the output gap variable in the model. All variables were included in the model by taking their logarithms to interpret the effects of changes in independent variables on the dependent variable at a fixed rate. Descriptive statistics regarding the data used in the study are as in the Table 2.

Table 2: Descriptive Statistics

\begin{tabular}{|c|c|c|c|c|c|}
\hline \multicolumn{6}{|c|}{ Brexit Period } \\
\hline & Mean & Median & Maximum & Minimum & Std. Dev. \\
\hline OIL & 60.64 & 62.33 & 80.47 & 45.07 & 9.67 \\
\hline IPI & 102.05 & 101.95 & 105.26 & 99.15 & 1.62 \\
\hline ER & 1.30 & 1.29 & 1.42 & 1.22 & 0.05 \\
\hline IMP & 120.12 & 120.50 & 123.80 & 117.10 & 1.95 \\
\hline PPI & 107.71 & 108.48 & 112.01 & 100.17 & 3.79 \\
\hline CPI & 2.03 & 2.00 & 2.80 & 0.80 & 0.53 \\
\hline \multicolumn{6}{|c|}{ Pre-Brexit Period } \\
\hline OIL & 90.21 & 103.11 & 124.93 & 30.80 & 26.41 \\
\hline IPI & 98.87 & 99.25 & 101.85 & 93.93 & 1.54 \\
\hline ER & 1.57 & 1.57 & 1.71 & 1.42 & 0.06 \\
\hline IMP & 128.38 & 129.00 & 136.60 & 118.30 & 5.09 \\
\hline PPI & 101.93 & 103.22 & 106.56 & 93.29 & 3.73 \\
\hline CPI & 2.08 & 2.40 & 4.50 & 0.20 & 1.14 \\
\hline
\end{tabular}

The SVAR model was used to limit the effect of the non-theoretical structure of the standard VAR model on the results. The constraints of the model, which is established when e structural shocks represent the residuals of the $\mu$ reduced VAR model, are as shown in matrix number 4.

$$
\left[\begin{array}{c}
\mu_{t}^{O \mathrm{I} L} \\
\mu_{t}^{O G} \\
\mu_{t}^{E R} \\
\mu_{t}^{\mathrm{I} M P} \\
\mu_{t}^{P P \mathrm{I}} \\
\mu_{t}^{C P \mathrm{I}}
\end{array}\right]=\left[\begin{array}{cccccc}
A_{11} & 0 & 0 & 0 & 0 & 0 \\
A_{21} & A_{22} & 0 & 0 & 0 & 0 \\
A_{31} & A_{32} & A_{33} & 0 & 0 & 0 \\
A_{41} & A_{42} & A_{43} & A_{44} & 0 & 0 \\
A_{51} & A_{52} & A_{53} & A_{54} & A_{55} & 0 \\
A_{61} & A_{62} & A_{63} & A_{64} & A_{65} & A_{66}
\end{array}\right]\left[\begin{array}{c}
e_{t}^{O i L} \\
e_{t}^{O G} \\
e_{t}^{E R} \\
e_{t}^{i M P} \\
e_{t}^{P P \mathrm{I}} \\
e_{t}^{C P \dot{\mathrm{I}}}
\end{array}\right]
$$

McCarthy (1999) uses a distribution chain to examine the transition of fluctuations in exchange rate and import prices to producer and consumer prices. In this model, inflation at a given distribution stage (producer, consumer and import) in period $t$ is assumed to involve several different components.

$$
\begin{aligned}
& \mathrm{\omega}_{t}^{\text {oil }}=E_{t-1}\left(\pi_{t}^{o i l}\right)+\varepsilon_{t}^{s} \\
& \tilde{y}_{t}=E_{t-1}\left(\tilde{y}_{t}\right)+a_{1 i} \varepsilon_{t}^{s}+\varepsilon_{t}^{d}
\end{aligned}
$$




$$
\begin{aligned}
& \Delta e_{t}=E_{t-1}\left(\Delta e_{t}\right)+b_{1 i} \varepsilon_{t}^{s}+b_{2 i} \varepsilon_{t}^{d}+\varepsilon_{t}^{e} \\
& \mathrm{\omega}_{t}^{i m p}=E_{t-1}\left(\mathrm{\omega}_{t}^{i m p}\right)+z_{1 i} \varepsilon_{t}^{s}+z_{2 i} \varepsilon_{t}^{d}+z_{3 i} \varepsilon_{t}^{e}+\varepsilon_{t}^{i m p} \\
& \omega_{t}^{p p i}=E_{t-1}\left(\mathrm{\omega}_{t}^{p p i}\right)+\beta_{1 i} \varepsilon_{t}^{s}+\beta_{2 i} \varepsilon_{t}^{d}+\beta_{3 i} \varepsilon_{t}^{e}+\beta_{4 i} \varepsilon_{t}^{i m p}+\varepsilon_{t}^{p p i} \\
& \mathrm{\omega}_{t}^{c p i}=E_{t-1}\left(\mathrm{\omega}_{t}^{c p i}\right)+\Omega_{1 i} \varepsilon_{t}^{s}+\Omega_{2 i} \varepsilon_{t}^{d}+\Omega_{3 i} \varepsilon_{t}^{e}+\Omega_{4 i} \varepsilon_{t}^{i m p}+\Omega_{5 i} \varepsilon_{t}^{p p i}+\varepsilon_{t}^{c p i}
\end{aligned}
$$

Where $\mathrm{C}_{t}^{o i l}$ is oil price, $\tilde{y}_{t}$ is the outputgap, $\Delta e$ is the first difference of the exchange rate, $E_{t-1}$ is the expectation of a variable conditional on information available at previous period, $s$ is supply, $\mathrm{d}$ is demand and $t$ is the time period. The order of the variables in the model is extremely important. Each variable in the model is explained by both its own changes and the changes of variables before it.

VAR models that were developed by Sims (1980) as an alternative to conventional systems of the simultaneous equation are the generalized form of autoregressive models for more than one variable. VAR models are based on three basic assumptions (Watson and Teelucksingh 2002),

- There is no internal-external distinction between the variables in the system,

- $\quad$ There is no zero-type constraint,

- $\quad$ There is no economic theory on which the model is based.

Therefore, in the sample bivariate $\operatorname{VAR}(p)$ model, a lagged variable as much as $p$ is added for both variables (Kirchgässner and Wolters 2007). A bivariate $\operatorname{VAR}(1)$ model including the variables $\omega$ and $\Omega$ is shown in matrix number 11 .

$$
\left[\begin{array}{c}
\omega_{t} \\
\Omega_{t}
\end{array}\right]=\left[\begin{array}{l}
a_{1} \\
a_{2}
\end{array}\right]+\left[\begin{array}{ll}
A_{11} & A_{12} \\
A_{21} & A_{22}
\end{array}\right]\left[\begin{array}{c}
\omega_{t-1} \\
\Omega_{t-1}
\end{array}\right]+\left[\begin{array}{c}
\varepsilon_{1 t} \\
\varepsilon_{2 t}
\end{array}\right]
$$

Equations 12 and 13 are obtained when matrix number 9 is converted into the equation form. In the following equations, $a$ represents the constant term, $A$ represents the coefficients of the model, $\varepsilon$ represents the error term.

$$
\begin{aligned}
& \mathrm{c}_{t}=a_{1}+A_{11} \mathrm{c}_{t-1}+A_{12} \Omega_{t-1}+\varepsilon_{1, t} \\
& \Omega_{t}=a_{1}+A_{21} \mathrm{c}_{t-1}+A_{22} \Omega_{t-1}+\varepsilon_{2, t}
\end{aligned}
$$

The main criticism for VAR models is that the model is not based on an economic theory as in the systems of simultaneous equations. In order to overcome this situation in SVAR models, the constraints suitable for economic theories are added to the VAR model, and structural shocks are used in the analysis. The sample bivariate structural VAR(1) model with independent variables $C$ and $\Omega$ is shown in matrix number 14 .

$$
\left[\begin{array}{cc}
1 & a_{12} \\
a_{21} & 1
\end{array}\right]\left[\begin{array}{c}
\omega_{t} \\
\Omega_{t}
\end{array}\right]=\left[\begin{array}{l}
a_{10} \\
a_{20}
\end{array}\right]+\left[\begin{array}{ll}
A_{11} & A_{12} \\
A_{21} & A_{22}
\end{array}\right]\left[\begin{array}{c}
\omega_{t-1} \\
\Omega_{t-1}
\end{array}\right]+\left[\begin{array}{c}
\varepsilon_{1 t} \\
\varepsilon_{2 t}
\end{array}\right]
$$

When matrix number 14 is written in the equation form:

$$
\begin{aligned}
& \mathrm{C}_{t}=a_{10}-\alpha_{12} \Omega_{t}+A_{11} \mathrm{C}_{t-1}+A_{12} \Omega_{t-1}+\varepsilon_{1, t} \\
& \Omega_{t}=a_{20}-\alpha_{21} \omega_{t}+A_{21} \omega_{t-1}+A_{22} \Omega_{t-1}+\varepsilon_{2, t}
\end{aligned}
$$

The closed form of equations 15 and 16 can be represented as in equation 17:

$$
B \Pi_{t}=\Gamma_{0}+\Gamma_{1} \Pi_{t-1}+\varepsilon_{t}
$$

When both sides of equation 17 are multiplied by $B^{-1}$, equation 18 is obtained:

$$
\Pi_{t}=B^{-1} \Gamma_{0}+B^{-1} \Gamma_{1} \Pi_{t-1}+B^{-1} \varepsilon_{t}
$$

When the variables in equation 18 are defined as" $\beta_{0}=B^{-1} \Gamma_{0} ", " \beta_{1}=B^{-1} \Gamma_{1}$ " and " $v=B^{-1} \varepsilon_{t}$ ", the standard form of the model shown in equation 19 is obtained:

$$
\Pi_{t}=\beta_{0}+\beta_{1} \Pi_{t-1}+v_{t}
$$


The analysis of variance decomposition is one of the most frequently used analyses to examine residuals by using the dynamic structure of VAR models. The interaction between the variables included in the VAR model can be observed by the analysis of variance decomposition. In other words, the analysis of variance decomposition shows the extent to which the prediction error variance of a variable is explained by other variables in the model (Brooks 2008).

$t+1$ reduced form of the bivariate VAR(1) model is shown in equation 20 (Cil 2018):

$\mathrm{C}_{t+1}=\beta_{0}+\beta_{1} \mathrm{CJ}_{t}+v_{t+1}$

The conditional expected value of the dependent variable in equation 21 is as follows:

$E_{t}\left(\mathrm{C}_{t+1}\right)=\beta_{0}+\beta_{1} \mathrm{C}_{1}$

when it is rewritten for $\mathrm{C}_{t+1}$ :

$\mathrm{C}_{t+2}=\beta_{0}+\beta_{1} \mathrm{C}_{t+1}+v_{t+2}=\beta_{0}+\beta_{1}\left(\beta_{0}+\beta_{1} \mathrm{C}_{t+1}+v_{t+1}\right)+v_{t+2}$

The conditional expected value of equation 22 is as follows:

$E_{t}\left(\mathrm{C}_{t+2}\right)=\left(I+\beta_{0}\right)+\beta_{0}+\beta_{1}^{2}+\mathrm{C}_{t}$

The prediction error of equation 23 is as follows:

$v_{t+2}=\beta_{1} v_{t+1}$

When it is generalized for $\mathrm{n}$ periods:

$E_{t}\left(\mathrm{C}_{t+n}\right)=\left(I+\beta_{1}+\beta_{1}^{2}+\cdots+\beta_{1}^{n-1}\right) \beta_{0}+\beta_{1}^{n} \mathrm{C}_{t}$

The prediction error of the equation generalized for $\mathrm{n}$ periods is as observed in equation 26 :

$v_{t+n}+\beta_{1} v_{t+n-1}+\beta_{1}^{2} v_{t+n-2}+\cdots+\beta_{1}^{n-1} v_{t+1}$

The prediction errors can also be obtained by moving averages. The moving averages form of the structural model is as in equation 27 (Enders 2014):

$\mathrm{C}_{t}=\mu+\sum_{i=0}^{\infty} \beta_{1}^{i} e_{t-i}$

If the prediction error for a period ahead is assumed as $\emptyset \varepsilon_{t+n-i}$, it can generally be represented as in equation 28 :

$\omega_{t+n}=\mu+\sum_{i=0}^{\infty} \emptyset_{i} \varepsilon_{t+n-i}$

The prediction error for $\mathrm{n}$ periods ahead is as follows:

$\omega_{t+n}-E_{t}\left(\omega_{t+n}\right)=\sum_{i=0}^{n-1} \Phi_{i} \varepsilon_{t+n-i}$

The prediction error for $\mathrm{n}$ periods ahead of the sequence $\varphi_{t}$ is presented below:

$\varphi_{t+n}-E_{t}\left(\varphi_{t+n}\right)=\Phi_{11}(0) \varepsilon_{\varphi t+n}+\Phi_{11}(1) \varepsilon_{\varphi t+n-1}+\cdots+\Phi_{11}(n-1) \varepsilon_{\varphi t+1}+\Phi_{12}(0) \varepsilon_{z t+n}+\Phi_{12}(1) \varepsilon_{z t+n-1}+\cdots+\Phi_{12}(n-$ 1) $\varepsilon_{z t+1}$

$\sigma_{\varphi}(n)^{2}$, the prediction error variance of $\varphi_{t+n}$, is calculated in the following way:

$\sigma_{\varphi}(n)^{2}=\sigma_{\varphi}^{2}\left[\Phi_{11}(0)^{2}+\Phi_{11}(1)^{2}+\cdots+\Phi_{11}(n-1)^{2}\right]+\sigma_{\varphi}^{2}\left[\Phi_{12}(0)^{2}+\Phi_{12}(1)^{2}+\cdots+\Phi_{12}(n-1)^{2}\right]$

The prediction error variance calculated for $\mathrm{n}$ periods ahead can be divided into rates for each shock. $\sigma_{\varphi}(n)^{2}$ rates resulting from the shocks in sequences $\varepsilon_{\varphi t}$ and $\varepsilon_{z t}$ are shown in equations 32 and 33 :

$\frac{\sigma_{\varphi}^{2}\left[\Phi_{11}(0)^{2}+\Phi_{11}(1)^{2}+\cdots+\Phi_{11}(n-1)^{2}\right]}{\sigma_{\varphi}(n)^{2}}$

$\frac{\sigma_{Z}^{2}\left[\Phi_{12}(0)^{2}+\Phi_{12}(1)^{2}+\cdots+\Phi_{12}(n-1)^{2}\right]}{\sigma_{\varphi}(n)^{2}}$ 
Variance decomposition shows the ratio of shocks from one variable to shocks from the other variable and is a useful tool for analyzing the correlations between economic variables (Enders 2014).

\section{EMPIRICAL RESULTS}

The most important assumption in econometric analyses, which include the time series, is the assumption that the variables included in the model are stationary. There are two main reasons why the stationarity assumption is important in time series analysis. Firstly, the behavior of a non-stationary time series can only be examined for the period under consideration. Therefore, it is not possible to generalize the results obtained for different time periods. Secondly, in the analyses performed with nonstationary series, the results of statistical and general significance tests are unreliable, and the presence of a relationship that does not actually exist can be found, which is called spurious regression in the econometric literature (Gujarati 2011).

In this study, the Augmented Dickey-Fuller (ADF) unit root test was used to test stationarity. The probability values of the unit root tests performed in both periods are shown in Table 3.

Table 3: ADF Test Unit Root Test Results

\begin{tabular}{llllllll}
\hline & \multicolumn{3}{c}{ Brexit Period } & \multicolumn{3}{c}{ Pre-Brexit Period } \\
\hline LOIL & -1.3471 & $\Delta$ LOIL & $-5.6773^{* * *}$ & LOIL & -2.1124 & $\Delta$ LOIL & $-5.9732^{* * *}$ \\
OG & -3.0749 & $\Delta$ OG & $-7.9545^{* * *}$ & OG & -3.1596 & $\Delta$ OG & $-12.8350^{* * *}$ \\
LER & -2.8429 & $\Delta$ LER & $-6.9010^{* * *}$ & LER & -1.6801 & $\Delta$ LER & $-7.7190^{* * *}$ \\
LIMP & -1.9792 & $\Delta$ LIMP & $-5.8540^{* * *}$ & LIMP & -1.7398 & $\Delta$ LIMP & $-8.5585^{* * *}$ \\
LPPI & -1.1553 & $\Delta$ LPPI & $-5.0203^{* * *}$ & LPPI & -1.4640 & $\Delta$ LPPI & $-6.0311^{* * *}$ \\
LCPI & $-3.5184 *$ & $\Delta$ LCPI & $-6.7934 * * *$ & LCPI & -1.9350 & $\Delta$ LCPI & $-7.5859 * * *$ \\
\hline
\end{tabular}

Note: L=Log, $\Delta=$ first difference.

$* * *, * * *$ indicates significance at 1,5 and 10 percent respectively.

Models include trend and intercept. The maximum lag for the ADF test is selected with the Schwert (1989).

According to the ADF test results, based on the 5 percent significance level, it was determined that all variables were not stationary with the level values. However, they became stationary when their first-order differences were taken. In addition to the ADF test, the correlograms of the series were examined, and it was observed that all variables were not stationary with the level values.

It was based on the information criteria for the determination of lag length. The appropriate lag length was determined to be 3 for the Brexit period and 5 for the pre-Brexit period. After determining the optimum lag length using the information criteria, the basic assumptions of the estimated model were examined. In the models established, White (No Cross Terms) was used to test heteroskedasticity, and the LM test was used to test autocorrelation. As seen in Table 4 and Table 5, there is no autocorrelation and variance problem in models. Accordingly, it was observed that the selected lag length was correct and that the established model provided the basic assumptions. From this point of view, it was concluded that the results obtained through the estimated model were reliable.

Table 4: Autocorrelation Test Results

\begin{tabular}{lllllll}
\hline & \multicolumn{3}{c}{ Pre-Brexit Period } & \multicolumn{2}{c}{ Brexit Period } \\
\hline Lag & Rao F-Stat & DF & Prob. & Rao F-Stat & DF & Prob. \\
\hline $\mathbf{1}$ & 0.9103 & $(36,130.1)$ & 0.6172 & 0.9684 & $(36,51.1)$ & 0.5342 \\
$\mathbf{2}$ & 0.8642 & $(36,130.1)$ & 0.6872 & 1.6712 & $(36,51.1)$ & $0.0453^{* *}$ \\
$\mathbf{3}$ & 1.1067 & $(36,130.1)$ & 0.3324 & 0.7714 & $(36,51.1)$ & 0.7919 \\
$\mathbf{4}$ & 0.8522 & $(36,130.1)$ & 0.7050 & 0.6902 & $(36,51.1)$ & 0.8778 \\
\hline
\end{tabular}

$* * *, * *, *$ indicates significance at 1,5 and 10 percent respectively.

Table 5: Heteroskedasticity Test Results

\begin{tabular}{llllll}
\hline \multicolumn{2}{c}{ Brexit Period } & \multicolumn{3}{c}{ Pre-Brexit Period } \\
\hline Chi-Sq & DF & Prob. & Chi-Sq & DF & Prob. \\
764.05 & 756 & 0.4116 & 1307.99 & 1,260 & 0.1692 \\
\hline
\end{tabular}


The analysis of variance decomposition, which was examined theoretically in the previous section, was used to determine the relationship between the variables. In this context, it was examined how much of changes in prices were caused by changes in the exchange rate. The results of the decomposition analysis of variance for the VAR models tested hypothetically are as Table 6.

Table 6: The Rate of Explanation of Price Indices by the Exchange Rate

\begin{tabular}{lcllll}
\hline Period & Price Index & $\mathbf{t}=\mathbf{1}$ & $\mathbf{t}=\mathbf{4}$ & $\mathbf{t}=\mathbf{8}$ & $\mathbf{t}=\mathbf{1 2}$ \\
\hline \multirow{2}{*}{ Brexit Period } & PPI & 19.94 & 16.79 & 16.70 & 16.45 \\
\multirow{2}{*}{ Pre-Brexit Period } & CPI & 3.49 & 3.59 & 6.52 & 6.41 \\
& PPI & 8.34 & 4.99 & 4.98 & 5.55 \\
& CPI & 1.83 & 1.96 & 3.40 & 4.44 \\
\hline
\end{tabular}

According to the results obtained in Table 6, 5.55 percent of changes in producer prices and 4.44 percent of changes in consumer prices in the pre-Brexit period were explained by changes in the exchange rate. In the Brexit period, these rates were 16.45 and 6.41 , respectively. In other words, the effect of Brexit on producer prices was more severe compared to consumer prices, and producer prices became more vulnerable to changes in the exchange rate.

When the analysis results were examined, it was observed that fluctuations in the exchange rate due to the uncertainty that occurred after the referendum were highly reflected, especially on consumer prices. When other studies in the literature were reviewed, it was observed that fluctuations in the exchange rate due to due to Brexit had similar characteristics with the exchange rate crises in developing countries. Mishkin (2002) offered the monetary authorities of countries the option to intervene in the exchange rate without leaving the inflation target on focus against the exchange rate fluctuations experienced in developing countries that adopted the inflation targeting regime. The UK's central bank should also consider this option in case the exchange rate increases cannot be controlled in the upcoming periods.

\section{CONCLUSION}

Along with the end of the Bretton Woods system and the countries abandoning the fixed exchange rate regimes and starting to implement the floating exchange rate regime, ERPT has become an extremely important issue. In particular, the political and economic developments that significantly affected the countries had a significant effect on the pass-through of the fluctuations in exchange rates to prices. Nowadays, ERPT has become an important indicator in evaluating the efficiency of monetary policies and the effects of the experienced political and economic events on national economies.

In this study, the effects of the Brexit process on ERPT were analyzed comparatively. According to the results obtained as a result of the analysis, the failure to resolve the Brexit process and the environment of uncertainty caused by this lack of solution had a weak effect on consumer prices. However, their effect on producer prices was extremely high. In other words, in the Brexit period, companies in the UK could not fully reflect the increase in production costs on consumer prices in order to maintain their share in the market. This situation caused a decrease in the profitability rates of the companies and created uncertainties about the future of the companies in the next years. It can be clearly observed by considering the economic indicators that this uncertainty has adverse effects on the UK's economy. However, the terms of the agreement should be determined precisely to examine the permanence of these adverse effects more properly.

Although the UK officially left the EU in the first month of 2020, the future of trade relations between the UK and the EU remains uncertain. Considering this environment of uncertainty and the COVID-19 pandemic that has caused the collapse in all world economies, it is not difficult to say that the UK economy will have hard times in the next period. Despite all these negative developments, new commercial partnerships expected to be established after Brexit are expected to generate significant dynamism both in the UK and different parts of the world.

\section{REFERENCES}

Baharumshah, A., Sirag, A., \& Soon, S.-V. (2017). Asymmetric exchange rate pass-through in an emerging market economy: The case of Mexico. Research in International Business and Finance, 247-259.

Baqueiro, A., Diaz de Leon, A., \& Torres, A. (2003). Fear of floating or fear of inflation? The role of the exchange rate pass-through. BIS Papers No:19, 338-354.

Belke, A., Dubova, I., and Osowoski, T. (2016). Policy uncertainty and international financial markets:the case of Brexit. Applied Economics 50 (3435): 3752-3770. doi:10.1080/00036846.2018.1436152.

Bouakez, H., \& Rebei, N. (2005). Has exchange rate pass-through really declined in Canada? Bank of Canada Working Paper, $2005-29$. 
Breinlich, H., Leromain, E., Novy, D., and Sampson, T. (2019). Exchange rates and consumer prices: evidence from Brexit. CEPR Discussion Paper 8001 (8): 1-50.

Brooks, C. (2008). Introductory Econometrics for Finance. Cambridge University Press.

Ca' Zorzi, M., Hahn, E., and Sanchez, M. (2007). Exchange rate pass-through in emerging markets. ECB Working Paper 739: 1-31.

Campa, J., and Goldberg, L. S. (2002). Exchange rate pass-through into import prices: a macro or micro phenomenon? NBER Working Paper 8934: 1-33.

Choudhri, E. U., and Hakura, D. S. (2006). Exchange rate pass-through to domestic prices: does the inflationary environment matter? Journal of International Money and Finance 25 (4): 614-639. doi:10.1016/j.jimonfin.2005.11.009.

Cil, N. (2018). Finansal Ekonometri. İstanbul: Der Yayınları.

Dhingra, S., Machin, S., and Overman, H. (2017). Local economic effects of Brexit. National Institute Economic Review 242 (1): 1-42. doi:10.1177/002795011724200112.

Dhingra, S., Ottaviano, G., Sampson, T., and Van Reenen, J. (2016b). The consequences of Brexit for UK trade and living standards. Centre for Economic Performance 2: 1-12.

Dhingra, S., Ottaviano, G., Sampson, T., and Van Reenen, J. (2016a). The impact of Brexit on foreign investment in the UK. Centre for Economic Performance 3: 1-10.

Enders, W. (2014). Applied Econometric Time Series. Wiley.

Goldberg, P. K., and Knetter, M. M. (1997). Goods prices and exchange rates: what have we learned. Journal of Economic Literature 5862: 12431272. doi:10.3386/w5862.

Gueorguiev, N. (2003). Exchange rate pass-through in Romania. IMF Working Paper 3 (130): 1-29.

Gujarati, D. (2011). Econometrics by Example. Palgrave Macmillan.

Hohlmeier, M., and Fahrholz, C. (2018). The impact of Brexit on financial markets-Taking stock. International Journal of Financial Studies 6 (3): 19. doi:10.3390/ijfs6030065.

Hooper, P., and Mann, C. L. (1989). Exchange rate pass-through in the 1980s: the case of US imports of manufactures. Brookings Papers on Economic Activity 1: 297-337. doi:10.2307/2534500.

Jiménez-Rodríguez, R., and Morales-Zumaquero, A. (2016). A new look at exchange rate pass-through in the G-7 countries. Journal of Policy Modeling 38(5): 985-1000. doi:10.1016/j.jpolmod.2016.06.007

Ito, T., and Sato, K. (2006). Exchange rate changes and inflation in post-crisis Asian economies: VAR analysis of the exchange rate pass-through. Journal of Money, Credit and Banking 52 (6): 1407-1438. doi:10.1111/j.1538-4616.2008.00165.x.

Kirchgässner, G., and Wolters, J. (2007). Introduction to Modern Time Series Analysis. Springer.

Leigh, D., and Rossi, M. (2002). Exchange rate pass-through in Turkey. IMF Working Paper 2 (204): 1-18.

Loloh, F. (2014). Exchange rate pass-through in Ghana. Bank of Ghana Staff Working Paper.

McCarthy, J. (1999). Pass-through of exchange rates and import prices to domestic inflation in some industrialized economies. BIS Working Papers 79: 1-37.

Menon, J. (1996). The degree and determinants of exchange rate pass-through: market structure, non-tariff barriers and multinational corporations. The Economic Journal 106 (435): 434-444. doi:10.2307/2235258.

Mishkin, F. (2002). Structural issues for successful inflation targeting in transition countries. Conference on Monetary Policy in the Environment of Structural Changes. National Bank of Poland, Falenty, Poland.

Ocran, M. K. (2010). Exchange rate pass-through to domestic prices: the case of South Africa. Prague Economic Papers 4: 291-306. doi:10.18267/j.pep.378.

Otani, A., Shiratsuka, S., \& Shirota, T. (2003). The decline in the exchange rate pass-through: evidence from Japanese import prices. Monetary and Economic Studies, 53-82.

Parsons, C. R., and Kiyotaka, S. (2008). New estimates of exchange rate pass-through in Japanese exports. International Journal of Finance and Economics 13 (2): 174-183. doi:10.1002/ijfe.337. 
Schiereck, D., Kiesel, F., and Kolaric, S. (2016). Brexit: (Not) another Lehman moment for banks? Finance Research Letters 19: $291-297$. doi:10.1016/j.frl.2016.09.003.

Schwert, G. (1989). Tests for unit roots: A Monte Carlo investigation. Journal of Business and Economic Statistics 7 (2): 147-159.

Sims, C. A. (1980). Macroeconomics and reality. Econometrica 48 (1): 1-48. doi:10.2307/1912017.

Stulz, J. (2007). Exchange rate pass-through in Switzerland: Evidence from vector autoregressions. Swiss National Bank Economic Studies 4, 1-32.

Taguchi, H., \& Bolortuya, J. (2019). Inflation targeting and the pass-through effect in Mongolia. Business and Economic Research, 9 (2), 57-71.

Taylor, J. B. (2000). Low inflation, pass-through, and the pricing power of firms. European Economic Review, 44 (7): 1389-1408. doi:10.1016/S00142921(00)00037-4.

Watson, P., and Teelucksingh, S. (2002). A Practical Introduction to Econometric Methods: Classical and Modern. University of the West İndies Press.

Welfens, P. J. (2018). BREXIT aus Versehen: Europaische Union zwischen Desintegration und neuer EU. Wuppertal: Springer.

Welfens, P. J., and Baier, F. J. (2018). Brexit and foreign direct investment: key issues and new empirical findings. International Journal of Financial Studies 6 (2): 1-21. doi:10.3390/ijfs6020046.

Winters, L., and Fernandes, A. (2018). The effect of exchange rate shocks on firm-level exports: evidence from the Brexit vote. Centre for Economic Policy Research DP13253: 1-30. 